\title{
Ethanol vapor treatment of 'Laetitia' plums stored under modified atmosphere
}

\author{
Francielle Regina Nunes ${ }^{1}$, Cristiano André Steffens ${ }^{2}$, Angélica Schmitz Heinzen ${ }^{3}$, Cristina Soethe ${ }^{4}$, \\ Marcelo Alves Moreira ${ }^{5}$, Cassandro Vidal Talamini do Amarante ${ }^{6}$
}

\begin{abstract}
The objective of this work was to evaluate the effect of ethanol vapor during storage in modified atmosphere on the ripening and maintenance of the postharvest quality of 'Laetitia' plums. The plums were obtained from an orchard in the municipality of Lages, SC. The experimental design adopted was completely randomized. The treatments evaluated were ethanol vapor doses $\left(0,2,4,6\right.$ and $8 \mathrm{~mL} \mathrm{~kg}^{-1}$ of fruit). The fruits were stored at $0.5 \pm 0.2^{\circ} \mathrm{C}$ and $92 \pm 2 \% \mathrm{RH}$ for 30 days. Upon their removal from storage followed by another three days in room conditions $\left(20 \pm 5^{\circ} \mathrm{C}\right.$ and $63 \pm 2 \% \mathrm{RH})$, the fruits were evaluated in relation to their physical and chemical attributes, incidence and intensity of internal browning, quantification of ethanol, acetaldehyde and ethyl acetate, and the activity of enzymes peroxidase and superoxide dismutase. The application of ethanol vapor was efficient in maintaining the fruits flesh firmness, reducing the evolution of the red coloring, and resulted in greater activity of enzymes peroxidase and superoxide dismutase. However, the doses evaluated were not efficient in reducing the internal browning.
\end{abstract}

Index terms: Prunus salicina L., postharvest, physiological disorder.

\section{Vapor de etanol durante o armazenamento de ameixas 'Laetitia' em atmosfera modificada}

Corresponding author: fran_rnd@hotmail.com

Received: December 14, 2018. Accepted: June 03, 2019.

Copyright: All the contents of this journal, except where otherwise noted, is licensed under a Creative Commons Attribution License.

\begin{abstract}
Resumo-O objetivo deste trabalho foi avaliar o efeito do vapor de etanol durante o armazenamento em atmosfera modificada sobre o amadurecimento e a manutenção da qualidade pós-colheita de ameixas 'Laetitia'. Foram utilizadas ameixas provenientes de um pomar do município de Lages-SC. O delineamento experimental utilizado foi o inteiramente casualizado. Os tratamentos avaliados foram doses de vapor de etanol $\left(0 ; 2 ; 4 ; 6\right.$ e $8 \mathrm{~mL} \mathrm{~kg}^{-1} \mathrm{de}$ fruto). Os frutos foram armazenados a $0,5 \pm 0,2^{\circ} \mathrm{C}$ e $92 \pm 2 \%$ de UR por 30 dias. Na saída do armazenamento seguido de mais três dias em condição ambiente $\left(20 \pm 5^{\circ} \mathrm{C}\right.$ e UR de $\left.63 \pm 2 \%\right)$, os frutos foram avaliadas quanto aos atributos físicoquímicos, incidência e intensidade de escurecimento da polpa, quantificação de etanol, acetaldeído e acetato de etila, e atividade das enzimas peroxidase e superóxido dismutase. A aplicação de vapor de etanol foi eficiente na manutenção da firmeza de polpa dos frutos, na redução da evolução da cor vermelha e apresentou maior atividade das enzimas peroxidase e superóxido dismutase. No entanto, as doses avaliadas não foram eficientes em reduzir o escurecimento da polpa.
\end{abstract}

Termos para indexação: Prunus salicina L., pós-colheita, distúrbio fisiológico. 


\section{Introduction}

The 'Laetitia' plum is a temperate-climate fruit, with a climacteric pattern of respiration and production of ethylene, factors that are associated with rapid maturation (ARGENTA et al., 2011). In Brazil, the plum harvesting period is short, comprising the months between November and January, which causes the input of imported fruits to be favored (BENATO et al., 2015). To regulate the national product's supply in the off-season, a viable alternative is to make use of cold storage. Temperature reduction is the main strategy used to conserve fruits. However, due to the high metabolic rate, the storage period is shortened (STEFFENS et al., 2018), because prolonged periods provide fruits with lower quality, characterized by great loss of flesh firmness (ALVES et al., 2009) and high incidence of internal browning (SINGH; SINGH, 2013).

Internal browning, a physiological disturbance affecting plums stored under cold storage, is considered a cold injury (SINGH; SINGH, 2013). This disorder occurs due to an oxidative process related to the production of reactive oxygen species, causing the peroxidation of lipids and reducing the efficiency of antioxidant systems, with consequent damage to cell membranes (SINGH; SINGH, 2012). In addition, internal browning may also be aggravated by the action of ethylene (CANDAN et al., 2011).

Thus, it is necessary to adopt new strategies to extend the storage period, among them modified atmosphere (MA) and the use of ethanol vapor. The reduction in temperature, the decrease in the partial pressure of $\mathrm{O}_{2}$ and the increase in the partial pressure of $\mathrm{CO}_{2}$ induced by the MA are the main factors that contribute to the maintenance of the product's quality and, consequently, to the reduction in postharvest losses (STANGER et al., 2017).

Studies have shown that ethanol vapor can be used as a complementary treatment to cold storage, aiming at the conservation of the fruits quality (LICHTER et al., 2006). Ethanol has effects on several climacteric fruits, slows senescence and inhibits the production of ethylene in plants, possibly improving the maintenance of quality attributes, depending on the species (PESIS, 2005).

As ethylene is involved in the development of internal browning and ethanol reduces ethylene production (ASODA et al., 2009; JIN et al., 2013), it is possible to utilize ethanol vapor as a tool to reduce this disorder. However, its effect may also be related to the lower production of reactive oxygen species, higher antioxidant capacity and/or membrane stability. Thus, the application of ethanol on fruit stored in MA can enhance the effects of this storage system to maintain the postharvest quality of 'Laetitia' plums.
The objective of this work was to evaluate the effect of ethanol vapor during storage in MA on the ripening and maintenance of the postharvest quality of 'Laetitia' plums, especially on internal browning and on the activity of antioxidant enzymes.

\section{Material and methods}

'Laetitia' plums from a commercial orchard in the city of Lages, 2016/2017 crop, were used in this work. After harvesting, the fruits were taken to the laboratory for homogenization of the experimental samples and subsequent treatments. Before the samples homogenization, the fruits with physical damage, rotting, cracking and nonstandard coloring (fruits with $>75 \%$ and $<25 \%$ of their surface covered in red) were eliminated. Each treatment consisted of four replicates and an experimental unit consisted of 20 fruits.

The experimental design adopted was completely randomized. Five doses of ethanol were evaluated: (control) and 2, 4, 6 and $8 \mathrm{~mL}$ ethanol $\mathrm{kg}^{-1}$ of fruit were used. Ten kilograms of fruit were packed in three lowdensity polyethylene (LDPE) plastic bags with $12 \mathrm{~m}$ thickness, one over the other, and tied with a string to keep the ethanol vapor within the package. A sachet (100 g per kg-1 of fruit) containing hydrated lime (Ca $(\mathrm{OH})_{2}$ ) was added to each package to absorb the $\mathrm{CO}_{2}$. The liquid ethanol volume required for each treatment was added to beakers with $100 \mathrm{~mL}$ capacity, which were placed inside the package with the fruit, where they remained throughout the entire storage period. For the control treatment, the fruits packaging during storage was exactly the same as in the other treatments, but without placement of the beaker containing ethanol. After the treatments application, the fruits were stored at $0.5 \pm 0.2^{\circ} \mathrm{C}$ and $92 \pm 2 \% \mathrm{RH}$ for 30 days.

Upon their removal from storage, rot incidence, weight loss, red color index (RCI), skin hue and respiratory and ethylene production rates were assessed. After three more days of shelf life $\left(20 \pm 5^{\circ} \mathrm{C}\right.$ and $63 \pm 2 \%$ $\mathrm{RH})$ to simulate the marketing period, they were evaluated regarding the red color index (RCI), skin color, respiratory and ethylene production rates, flesh firmness, titratable acidity (TA), soluble solids (SS) and the incidence and intensity of internal browning according to the methodology described by STANGER et al. (2017), whereas the loss of mass, quantification of the fermentation products (ethyl acetate, ethanol and acetaldehyde), enzymatic activity of peroxidase (POD) and superoxide dismutase (SOD) were assessed according to the methodology described below.

Weight loss (\%) was evaluated by calculating the difference between the weight of each sample before 
subjecting them to cold storage and upon their removal from the chamber.

For the fermentation products quantification, a gas chromatograph was used, "Clarus 580 GC" model (PerkinElmer, USA), the oven's temperature having been kept constant at $55^{\circ} \mathrm{C}$, with 3 minute run time, nitrogen carrier gas with a flow of $2 \mathrm{~mL}$ per minute, and temperate of the detector and injector set at 250 and $180^{\circ} \mathrm{C}$, respectively. The standard used was $100 \mathrm{ppm}$ for ethyl acetate and acetaldehyde, and $200 \mathrm{ppm}$ for ethanol, obtained by diluting these substances in pure distilled water. Twenty $\mathrm{mL}$ samples were obtained from the juice produced with the fruits, which were stored in "headspace" vial tubes with $50 \mathrm{~mL}$ capacity. After keeping them for an hour in a water bath at $70^{\circ} \mathrm{C}, 1 \mathrm{~mL}$ syringes with the content retained in the "headspace" of each tube were sampled.

To obtain the enzyme extract, the plant tissue was macerated in liquid nitrogen, after which $0.3 \mathrm{~g}$ of pulp tissue was added to $3 \mathrm{~mL}$ of extraction medium consisting of $0.1 \mathrm{M}$ potassium phosphate buffer (Vetec, Duque de Caxias, Brazil), $6.8 \mathrm{pH}, 0.1 \mathrm{mM}$ ethylenediaminetetraacetic acid (EDTA) (Dinâmica, Diadema, Brazil) and $1 \mathrm{mM}$ phenylmethylsulfonyl fluoride (PMSF) (Sigma, St. Louis, USA). The peroxidase activity was determined by adding $600 \mu \mathrm{L}$ of enzyme extract in a $25 \mathrm{mM}$ potassium phosphate buffer, $6.8 \mathrm{pH}, 20 \mathrm{mM}$ guaiacol and $20 \mathrm{mM} \mathrm{H}_{2} \mathrm{O}_{2}$. The decrease in absorbance at $25^{\circ} \mathrm{C}$ was measured for 1 minute of the reaction with the aid of a microplate reader, EnSpire model (PerkinElmer, USA), at $420 \mathrm{~nm}$ for 1 minute. The POD activity was determined based on the slope of the line in the range from 0 to 1 minutes and expressed as $\mu \mathrm{mol} \mathrm{\text {min } ^ { - 1 } \mathrm { mg } \text { protein }}{ }^{-1}$.

The activity of superoxide dismutase (SOD) was determined according to the method proposed by Del Longo et al. (1993), with modifications. To obtain the extraction medium, the plant tissue was macerated in liquid nitrogen, after which $0.3 \mathrm{~g}$ of pulp tissue was added to $3 \mathrm{~mL}$ of extraction medium consisting of $0.1 \mathrm{M}$ potassium phosphate buffer (Vetec, Duque de Caxias, Brazil), $6.8 \mathrm{pH}, 0.1 \mathrm{mM}$ ethylenediaminetetraacetic acid (EDTA) (Dinâmica, Diadema, Brazil) and $1 \mathrm{mM}$ phenylmethylsulfonyl fluoride (PMSF) (Sigma, St. Louis, USA). After homogenization in a mortar, kept on ice, the samples were placed in Eppendorf tubes and centrifuged at $4^{\circ} \mathrm{C}$ for 15 minutes, at $10,000 \mathrm{rpm}$, with the aid of a Hitachi ${ }^{\circledR}$ centrifuge, 5810R model (Tokyo, Japan). Subsequently, $50 \mu \mathrm{L}$ of supernatant with $2.95 \mathrm{~mL}$ of reaction medium was added to the reaction medium, which was composed of $50 \mathrm{mM}$ sodium phosphate buffer (Vetec, Duque de Caxias, Brazil), $7.8 \mathrm{pH}, 13 \mathrm{mM}$ methionine (Vetec, Duque de Caxias, Brazil), $75 \mathrm{uM}$ nitro-blue tetrazolium (NBT) (Vetec, Duque de Caxias,
Brazil), 0.1 mM EDTA(Dinâmica, Diadema, Brazil) and $2 \mathrm{uM}$ riboflavin (Vetec, Duque de Caxias, Brazil), which were placed in glass containers covered with and without aluminum foil and then exposed to light for 10 minutes. The quantification of enzymatic activity was determined at $560 \mathrm{~nm}$ wavelength with the aid of a microplate reader, EnSpire model (PerkinElmer, USA), and expressed as $\mu \mathrm{mol} \mathrm{\text {min } ^ { - 1 } \text { mg protein }}{ }^{-1}$.

The protein present in the enzyme extract was determined by using the colorimetric method of Bradford (1976).

The $\%$ values were previously transformed by using the arc sine formula $[(x+0.5) / 100]^{1 / 2}$. The data were subjected to an analysis of variance and the means were subjected to a regression analysis for the ethanol doses. The statistical analysis was performed with the aid of the R software (R core team 2011).

\section{Results and discussion}

At the time of harvest, the hue of the fruits skin in the most and least red region of the epidermis $\left(h^{\circ}\right)$ was 25.7 and 74.5, respectively; flesh firmness was $39.5 \mathrm{~N}$; SS content was $9.6^{\circ}$ Brix, and titratable acidity was 12.5 $\mathrm{mEq} 100 \mathrm{~mL}^{-1}$.

Regarding the fermentation products, there was a linear increase in the concentration of ethyl acetate, ethanol and acetaldehyde with the increase in the ethanol doses (Figure 1).

High concentrations of the fermentation product (ethanol, acetaldehyde and ethyl acetate) in the fruits can produce an off-flavor and reduce their quality, causing internal browning (WRIGHT et al., 2015). Although large quantities of fermentation compounds may cause undesirable characteristics in the fruits, small amounts can enhance their aroma and flavor. Echeverria et al. (2008) observed that 'Mondial Gala' apples, which had the presence of ethyl acetate, were more accepted by consumers, justifying the fact that the presence of this ester, to a limited extent, can contribute to the fruits aroma. Quantitatively, esters are the main components of the volatile composition of plums, ethyl acetate being one of them (PINO; QUIJANO, 2012). The off-flavors are related to increased concentrations of ethanol and ethyl acetate, but not acetaldehyde (LARSEN; WATKINS, 1995). However, in this study, it was not possible to assess the presence of off-flavors because sensory analysis was not performed. In addition, other factors are important for the consumers acceptance, such as the firmness and acidity of the fruit, and these characteristics can be affected by the fermentation products (WEBER, 2016). Also, according to this author, the maintenance of the fruits quality promoted by fermentation products 
such as ethanol and acetaldehyde is due to their effect on the ethylene synthesis route, respiratory metabolism, the production of aromas and the expression of some enzymes and proteins.

The ethylene production rate after the fruits were removed from the storage chamber was not affected by the ethanol doses (data not shown). After three days of exposure of the fruit to room conditions, ethylene production decreased with the increase in the ethanol dose up to the dose of $6 \mathrm{~mL}$ of ethanol $\mathrm{kg}^{-1}$ of fruit (Figure 1).

In 'Yumeiren' melons (JIN et al., 2013) and broccoli (ASODA et al., 2009), ethanol vapor also reduced the ethylene production rate. In broccoli, ethanol inhibited ethylene production through the reduction in the activity of enzymes 1-aminocyclopropane-1carboxylate synthase and oxidase (ACC synthase and ACC oxidase) (ASODA et al., 2009). In melons, the inhibition of ethylene biosynthesis occurred due to the suppression of the expression of genes CM-ACO1, $\mathrm{CM}-\mathrm{ACO} 2, \mathrm{CMACO} 3$ e CM-ACS1, CM-ACS2 and CM-ACS3 during storage (JIN et al. 2013). According to Bai et al. (2004), ethanol action mechanism is related to the endogenous concentration of acetaldehyde, which is a biologically active factor that affects the production of ethylene. Weber et al. (2016) found that the production of acetaldehyde in apples after eight months of storage reduced ethylene synthesis in the fruits. The acetaldehyde present in tissue, resulted from the conversion of ethanol or from the application of acetaldehyde itself, seems to be a determining factor in the inhibition of ripening, characterized by an increase in the synthesis of ethylene (BRACKMANN et al., 2009), as it acts by directly inhibiting the action of enzymes ACC synthase and ACC oxidase, which act in the conversion of ACC into ethylene (BOTH et al., 2014). In this study, the treatments with low ethylene production rate had higher concentrations of acetaldehyde, ethanol and ethyl acetate.

The fruits respiration rate was not affected by the ethanol doses (data not shown); however, some studies show that non-toxic concentrations of exposure to ethanol may reduce it (WEBER et al, 2016).

The red color index (RCI) of the fruits after their removal from the chamber decreased with the increase in ethanol doses (Figure 2). Although the application of ethanol vapor had a significant effect, the differences observed were not substantial, as the RCI shown by the control was 3.84 and the one shown by the dose of 8 $\mathrm{mL}$ of ethanol per kg-1 of fruit was 3.60 , which are very similar values. After three days under room conditions, no effect of the ethanol doses on the RCI was observed (data not shown).
Upon the samples removal from the chamber, the hue angle $\left(h^{\circ}\right)$ in the least red region of the fruit was not affected by the application of ethanol (data not shown). In the reddest region, the increase in the ethanol doses resulted in higher hue angle values $\left(h^{\circ}\right)$ (Figure 2). After three days under room conditions, the hue angle $\left(h^{\circ}\right)$ in both regions of the fruit showed higher values with the dose of $4 \mathrm{~mL}$ of ethanol $\mathrm{kg}^{-1}$ of fruit (Figure 3).

After 30 days of storage, upon the samples removal from the chamber, the luminosity $(\mathrm{L})$ in the most and least red regions of the fruit was not affected by the application of ethanol (data not shown). However, after three more days under room conditions, the $\mathrm{L}$ value was greater in the most and least red regions of the fruit with a dose of $4 \mathrm{~mL}$ of ethanol per $\mathrm{kg}^{-1}$ of fruit (Figure 3).

The results of the attributes related to the fruits color show the benefits of the treatment with ethanol vapor in the delay of the evolution of red coloring in the fruits, up to a dose of $4 \mathrm{~mL}$ of ethanol $\mathrm{kg}$ of fruit, especially shelf life however, its effectiveness may be related to the dose used. Skin hue is an important indicator of the fruits' stage of ripening (PALAPOL et al., 2009). The slower development of the hue of the fruits epidermis (higher hue angle and L values) after the application of ethanol vapor must be related to the decrease in the biosynthesis and action of ethylene, as ethylene stimulates the synthesis and activity of enzymes such as oxidases and chlorophyllases, which are responsible for the change in the fruits color (STANGER et al., 2014).

Flesh firmness improved with the increase in ethanol doses (Figure 4). The positive effect of the ethanol treatment on the maintenance of flesh firmness corroborates the study by Ritenour et al. (1997), with melons, and the one by Bai et al. (2011), with apples. Lurie and Pesis (1998) reported that the activity of enzymes associated with the cell wall degradation such as polygalacturonase was reduced by the action of ethanol on peaches and nectarines. The maintenance of pulp firmness can also be explained by the fact that the ethylene produced by the fruit regulates the activity of enzymes associated with the degradation of cell wall components and with the loss of pulp firmness, such as $\beta$-galactosidase and endoglucanase in avocado and polygalacturonase, pectin methylesterase, $\beta$-galactosidase and cellulases in papaya (FONTES et al., 2008). In 'Laetitia' plums (STEFFENS et al., 2013), melons (JIN et al., 2013) and tomatoes (TZAORTAKIS; ECONOMAKIS, 2007), greater pulp firmness was related to the strong decrease in the biosynthesis of ethylene. In the present work, the fruits with greater flesh firmness also had lower ethylene biosynthesis rate, but the fruits of all treatments, including the one without application of ethanol, showed flesh firmness 
higher than 9 N. Plums with flesh firmness lower than 9 $\mathrm{N}$ are considered improper for consumption (BENATO et al., 2015).

The nternal browning incidence was slightly higher with the application of $4 \mathrm{ml}$ of ethanol $\mathrm{kg}^{-1}$ of fruit (Figure 4). However, the percentage of fruit with disorder was high in all treatments $(>90 \%)$. According to Pesis (2005), the effect of ethanol on the reduction of cold damage has been observed for other fruit species and is associated with the reduction in the membrane viscosity through the increase in lipid fluidity.

Ethanol has no effect on internal browning intensity (data not shown). In plums, it has been proposed that internal browning happens due to an oxidative process related to the production of reactive oxygen species causing lipid peroxidation, with consequent damage to cell membranes (SINGH; SINGH, 2013). The pulp color is an important aspect to be considered in relation to the acceptability of the fruits by consumers. In the sensory evaluation, the 'Laetitia' plums which had L values lower than 41.3 showed rejection by consumers above $90 \%$ when evaluated in terms of pulp color (STEFFENS et al., 2013; CORRÊA et al., 2011).

The activity of superoxide dismutase (SOD) showed quadratic behavior, reducing activity with intermediate doses of ethanol and having greater activity at a dose of $8 \mathrm{~mL}$ of ethanol $\mathrm{kg}$ of fruit (Figure 5). The dose of $8 \mathrm{~mL}$ of ethanol $\mathrm{kg}$ of fruit also resulted in higher activity of the peroxidase enzyme (POD) (Figure 5). Han et al. (2006) found that the activity of enzymes SOD and POD was higher in broccoli treated with ethanol during storage.

SOD plays an important role in helping and eliminating free radicals. High SOD activity is related to the increased production of hydrogen peroxide, which is a key molecule for various metabolic processes within the cell, from free radical production to lignification and production of phenolic compounds, also acting as a trigger for acquired systemic resistance responses (NUNES et al., 2015). The increase in SOD and POD activities is a consequence of the system's ability to delay senescence (HAN et al., 2006).

There was no effect on titratable acidity (TA) and soluble solids (SS) in fruits treated with ethanol (data not shown), similarly to the results of Ritenour et al. (1997). The maintenance of TA is important to ensure balance with the SS. It has been shown that acetaldehyde and ethanol can induce physiological and biochemical responses in fruits, increasing the sugar content and reducing acidity (PESIS, 2005). Benato et al. (2015) observed that ethanol favored an increase in the content of soluble solids of plums stored under cold storage.
The rot incidence after storage and after shelf life was not affected by the treatments (data not shown). The application of fermentation products (ethanol and acetaldehyde) increased the occurrence of rot in 'Royal Gala' apples, possibly due to the use of very high doses (BOTH et al., 2014). However, in this study, this behavior was not verified.

In general, positive effects of the use of ethanol vapor on the delay of the ripening of 'Laetitia' plums and on the content of POD and SOD enzymes involved in the antioxidant mechanism were observed. However, the hypothesis that the implementation of ethanol vapor during the storage of 'Laetitia' plums in modified atmosphere would substantially reduce internal browning was not confirmed. It is possible that the tested ethanol doses were too high, which means that intermediate doses between 0 and $2 \mathrm{~mL}$ of ethanol $\mathrm{kg}^{-1}$ of fruit should be evaluated. 

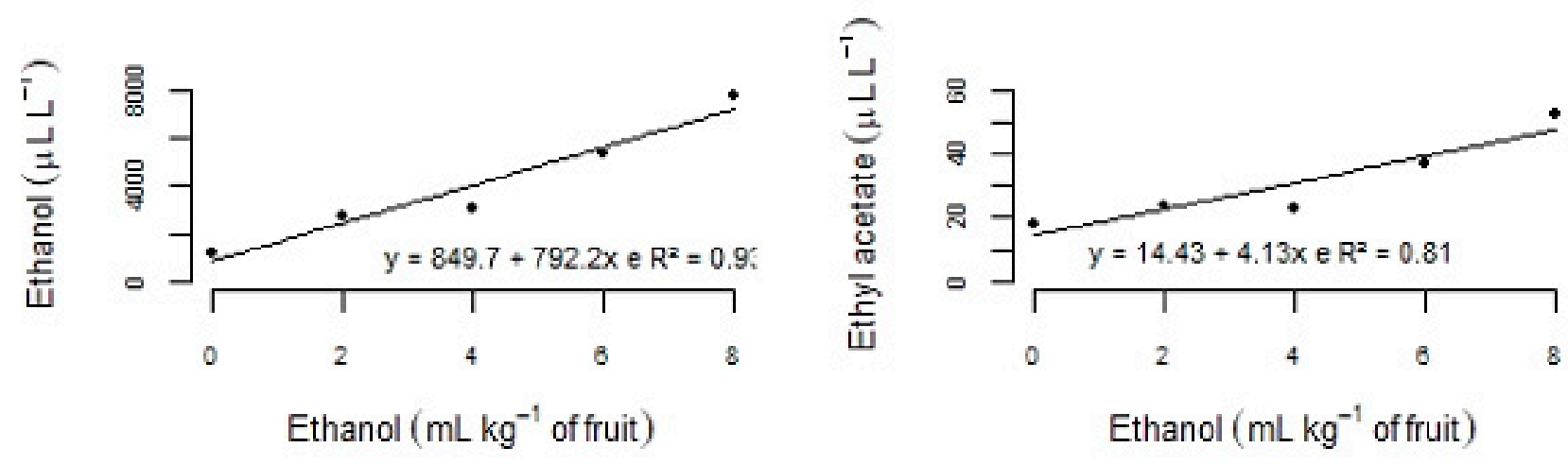

I1
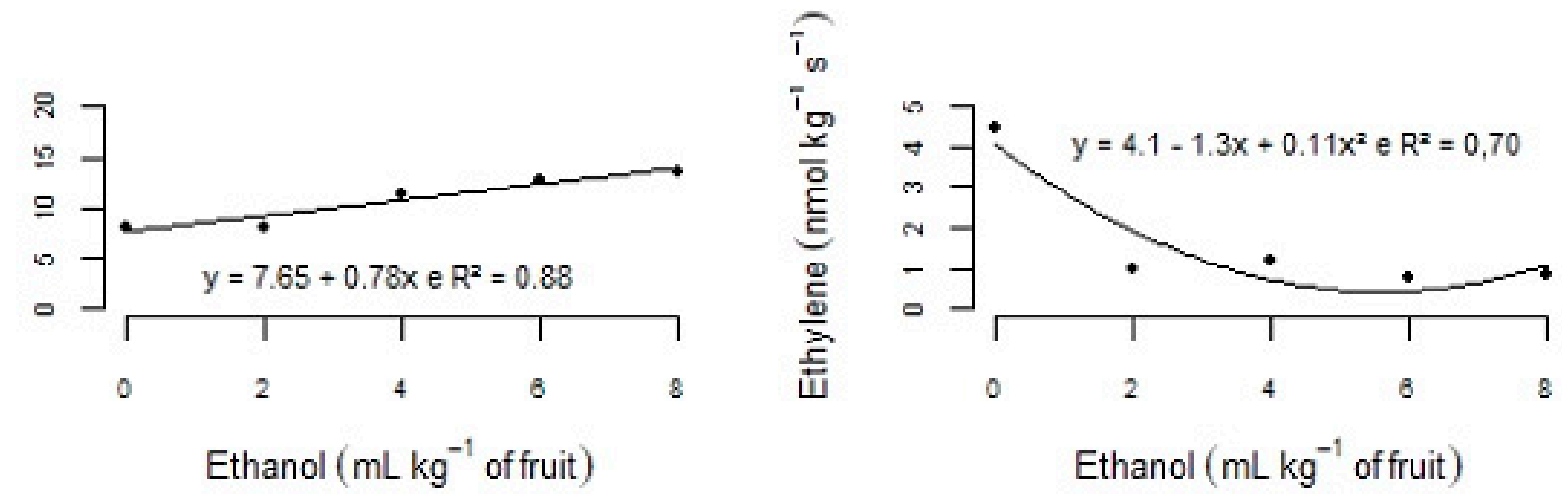

Figure 1. Concentration of ethanol, ethyl acetate and acetaldehyde, and ethylene production rate of 'Laetitia' plum submitted to different doses de ethanol during modified atmosphere storage at $0.5 \pm 0.2{ }^{\circ} \mathrm{C}$ and $92 \pm 2 \% \mathrm{RH}$, after 30 days of storage plus three days shelf life $\left(20 \pm 5^{\circ} \mathrm{C}\right.$ and $\left.63 \pm 2 \% \mathrm{RH}\right)$.
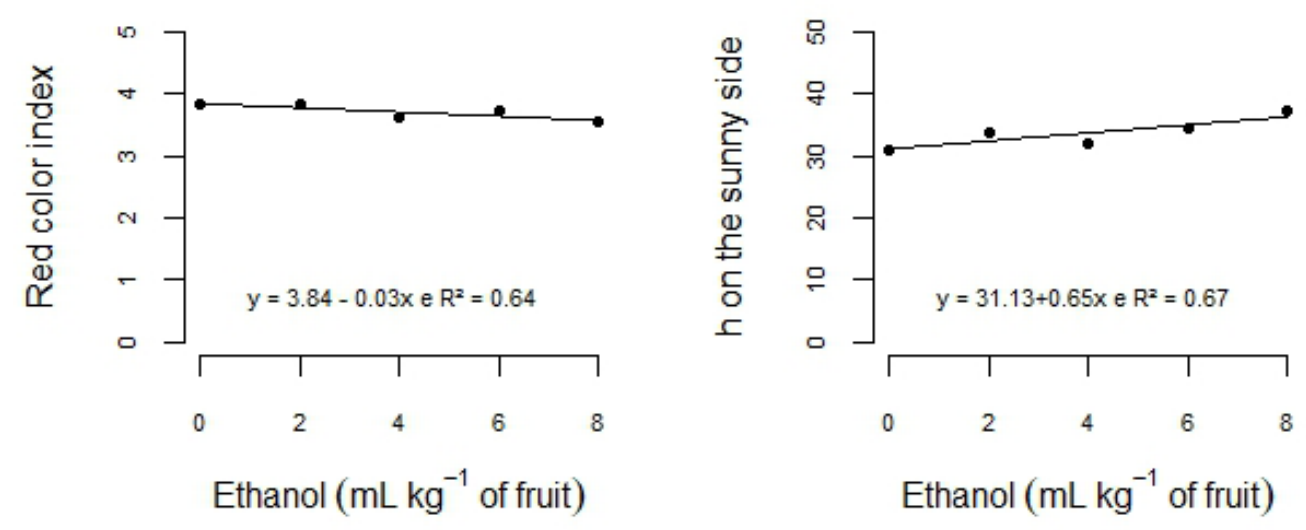

Figure 2. Red color index and hue angle $\left(\mathrm{h}^{\circ}\right)$ on the sunny side of 'Laetitia' plum submitted to different doses de ethanol during modified atmosphere storage at $0.5 \pm 0.2{ }^{\circ} \mathrm{C}$ and $92 \pm 2 \% \mathrm{RH}$, after 30 days of storage. 
$\frac{\Phi}{0}$
$\frac{0}{0}$
$\frac{0}{0}$
$\frac{5}{0}$
$\frac{1}{5}$
$\frac{5}{0}$
ᄃ

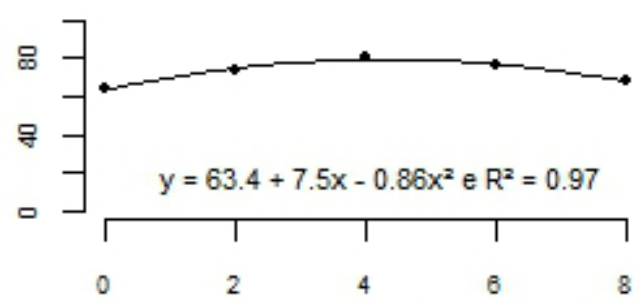

Ethanol ( $\mathrm{mL} \mathrm{kg}^{-1}$ of fruit)

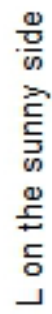

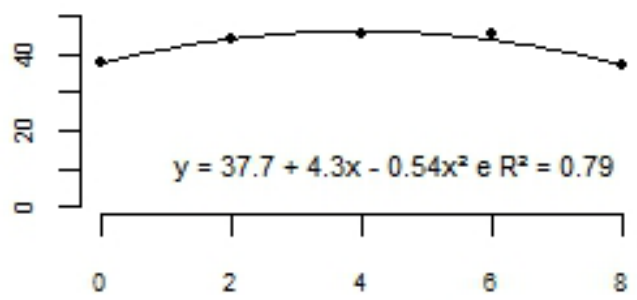

Ethanol ( $\mathrm{mL} \mathrm{kg}^{-1}$ of fruit)

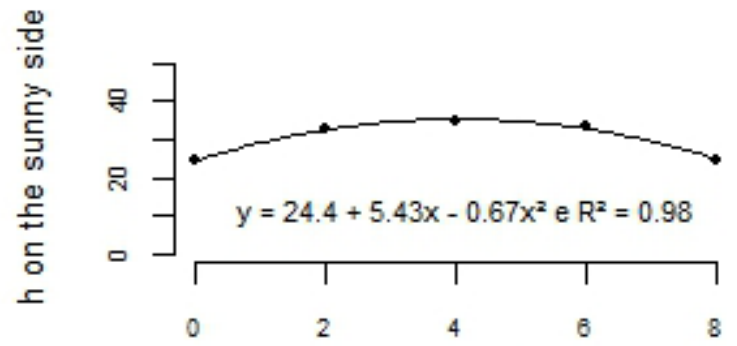

Ethanol ( $\mathrm{mL} \mathrm{kg}^{-1}$ of fruit)

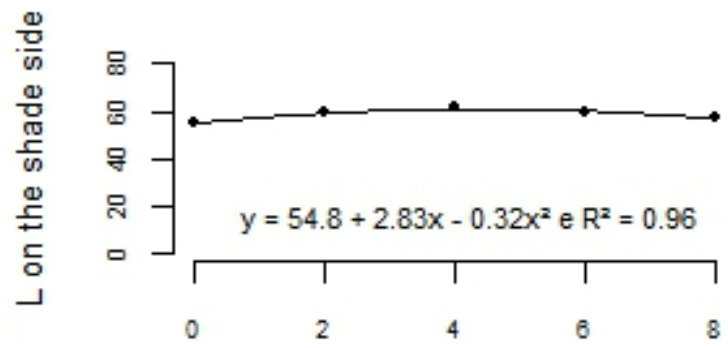

Ethanol ( $\mathrm{mL} \mathrm{kg}^{-1}$ of fruit)

Figure 3 - Hue angle $\left(\mathrm{h}^{\circ}\right)$ and lightness (L) on the shade and sunny sides of 'Laetitia' plum submitted to different doses de ethanol during modified atmosphere storage at $0.5 \pm 0.2{ }^{\circ} \mathrm{C}$ and $92 \pm 2 \% \mathrm{RH}$, after 30 days of storage plus shelf life $\left(20 \pm 5^{\circ} \mathrm{C}\right.$ and $\left.63 \pm 2 \% \mathrm{RH}\right)$.
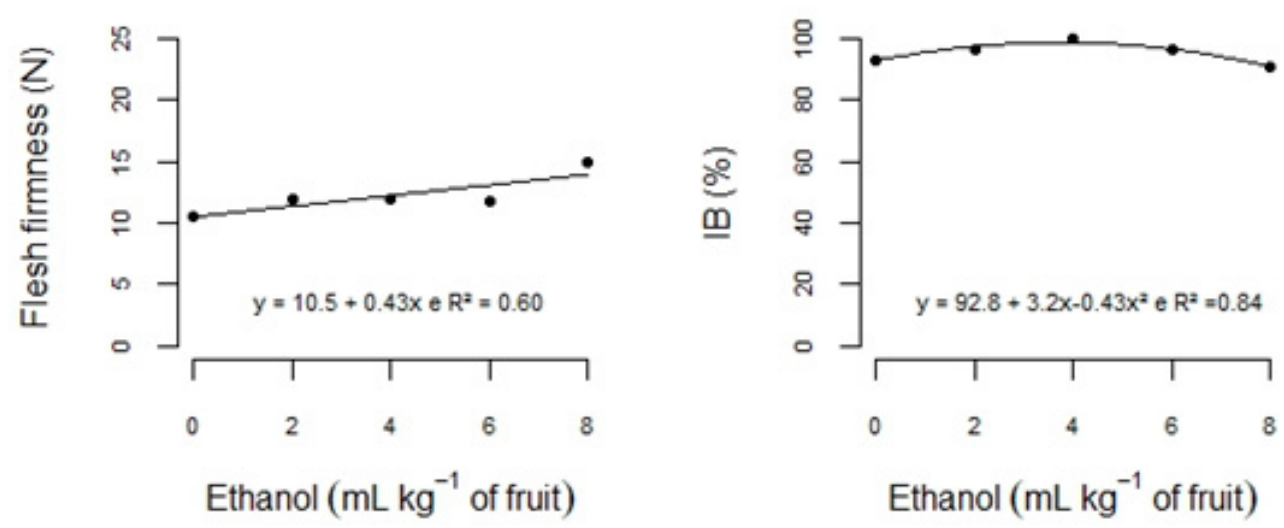

Figure 4 - Flesh firmness and incidence of internal browning (IB) in 'Laetitia' plum submitted to different doses de ethanol during modified atmosphere storage at $0.5 \pm 0.2{ }^{\circ} \mathrm{C}$ and $92 \pm 2 \% \mathrm{RH}$, after 30 days of storage plus three days. 

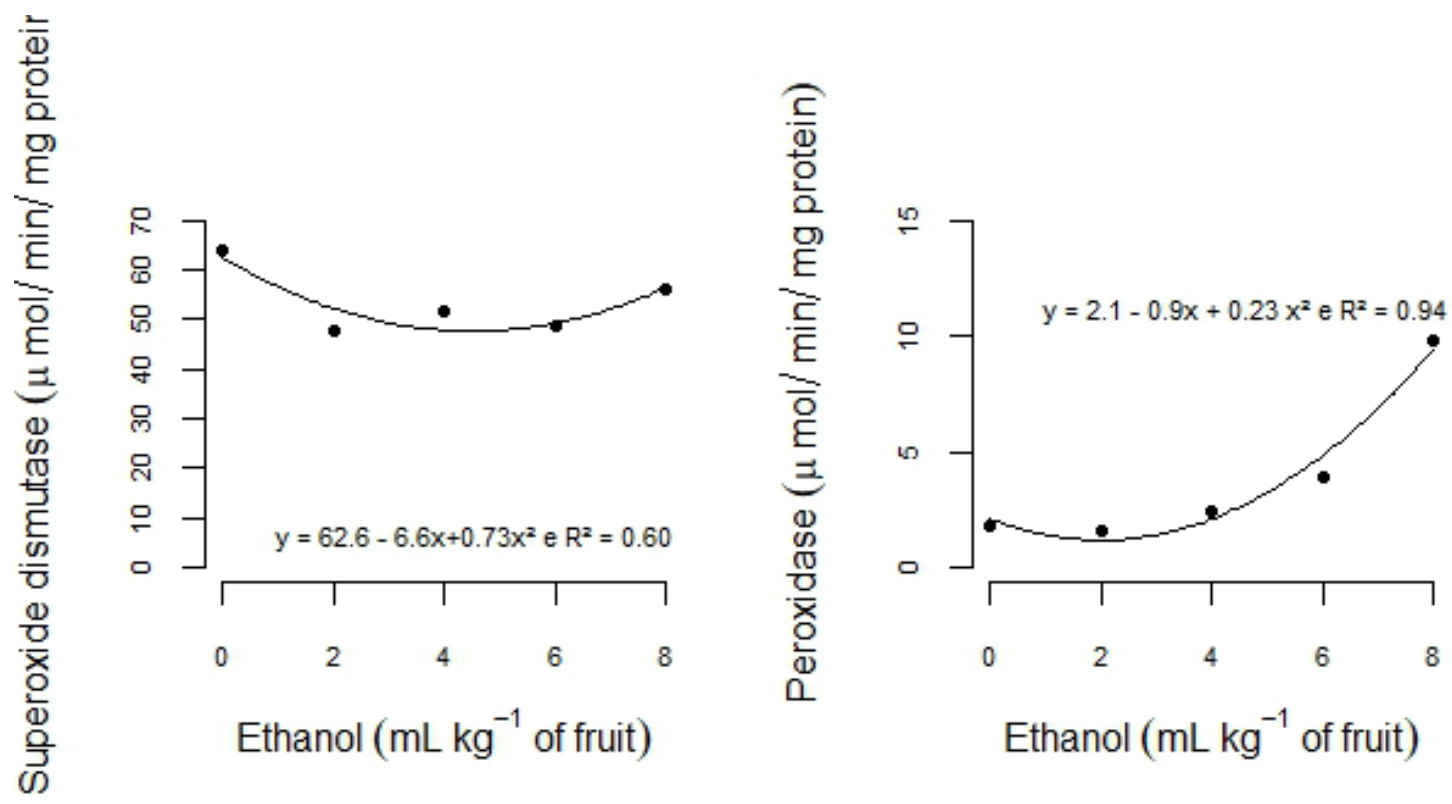

Figure 5 - Activity of superoxide dismutase and peroxidase in 'Laetitia' plum submitted to different doses de ethanol during modified atmosphere storage at $0.5 \pm 0.2{ }^{\circ} \mathrm{C}$ and $92 \pm 2 \% \mathrm{RH}$, after 30 days of storage plus three days shelf life $\left(20 \pm 5^{\circ} \mathrm{C}\right.$ and $\left.63 \pm 2 \% \mathrm{RH}\right)$.

\section{Conclusion}

The application of ethanol vapor associated with storage in MA was efficient in delaying the ripening of 'Laetitia' plums, especially in relation to the reduction in the evolution of red coloring and loss of flesh firmness. The dose of $8 \mathrm{~mL}$ of ethanol per $\mathrm{kg}$ of fruit promoted the increase in the enzymatic activity of superoxide dismutase and peroxidase. However, the ethanol dosages used in this study were not effective in reducing the incidence of internal browning in 'Laetitia' plums.

\section{Acknowledgments}

The authors thank the National Council for Scientific and Technological Development (CNPq), the Research Support Program of the Santa Catarina State University (UDESC), the Foundation for Research and Innovation of the State of Santa Catarina (FAPESC), as well as the Coordination of Higher Education Personnel Training (CAPES) for the financial support to this project and for the fellowships granted.

\section{References}

ALVES, E.O.; STEFFENS, C.A.; AMARANTE, C.V.T.; PAVANELLO, E.P.; BRACKMANN, A. Manejo do etileno durante o armazenamento de ameixas 'Laetitia' em atmosfera controlada. Ciência Rural, Santa Maria, v.39, n.9, p.2445- 245, 2009.

ARGENTA, L. C.; AMARANTE, C.V.T.; SHIRAYAMA, D.; SCOLARO, A.M.T.; AYUB, R.A. Controle do escurecimento interno de ameixas durante o armazenamento pelo manejo do ponto de colheita e do etileno. Revista Brasileira de Fruticultura, Jaboticabal, v. 33, n. 2, p. 376-385, 2011.

ASODA, T.; TERAI, H.; KATO, M.; SUZUKY, Y. Effects of postharvest ethanol vapor treatment on ethylene responsiveness in broccoli. Postharvest Biology and Technology, Amsterdam, v.52, n.2, p.216-220, 2008

BAI.J.H.; PLOTTO.A.; SPOTTS. R.; RATTANAPANONE. N. Ethanol vapor and saprophytic yeast treatments reduce decay and maintain quality of intact and fresh-cut sweet cherries. Postharvest Biology and Technology, Amsterdam, v. 62, n. 02, p. 204-212, 2011 
BAI, J.H.; BALDWIN, E.A.; FORTUNY, R.C.S.; MATTHEIS, J.P.; STANLEY, R.; PERERA, C.; BRECHT, J.K. Effect of pretreatment of intact 'Gala' apple with ethanol vapor, heat,or 1- methylcyclopropene on quality and shelf life of fresh-cut slices. Journal of the American Society for Horticultural Science, Alexandria, v.129, n.4, p. 583-593, 2004.

BENATO, L. A.; CASTRO, M. F. P M.; SIGRIST, J. M. M.; ANJOS, V. D. A.; VALENTINI, S. R. T. Qualidade de ameixas cv. Reubennel após tratamento com produtos alternativos, refrigeração e climatização. Revista Brasileira Fruticultura, Jaboticabal, v.37, n.2, p.324334, 2015.

BOTH, V.; BRACKMANN, A.; WEBER, A.; ANESE, R.O.; THEWES, F.R. Estresse inicial por baixo oxigênio seguido do armazenamento em atmosfera controlada de maçãs 'Royal Gala'. Revista Ciência Agronômica, Fortaleza, v. 45, n. 4, p. 708-717, 2014.

BRACKMANN, A.; GIEHL, R.F.H.; EISERMANN, A.C.; WEBER, A.; HELDWEIN, A.B. Inibição da ação do etileno e temperatura de armazenamento no padrão de amadurecimento de tomates. Ciência Rural, Santa Maria, v.39, n.6, p.1688-1694, 2009.

BRADFORD, M.M. A rapid and sensitive method for the quantitation of microgram quantities of protein utilising the principle of protein - dye binding. Analytical Biochemistry, San Diego, v.72, p.248-254, 1976. (1)

CANDAN, A.P.; GRAEL, J.; LARRIGAUDIÉRE, C. Postharvest quality and chilling injury of plums: benefits of 1-methylcyclopropene. Spanish Journal of Agricultural Research, Madrid, v.9, n.2, p.554-564, 2011.

CORREAA, T. R.; STEFFENS, C.A.; TANAKA, H.; AMARANTE, C.V.T.; BRACKMANN, A.; ANESE, R.O. Manejo do etileno em ameixas 'laetitia' armazenadas sob atmosferas controlada e modificada ativa. Revista Brasileira de Fruticultura, Jaboticabal, v.33, n.3, p.723729, 2011.

ECHEVERRIA, G.; GRAELL, J.; LARA, I.; LÓPEZ, M.L. Physicochemical measurements in 'Mondial Gala ${ }^{\circledR}$ ' apples stored at diferente atmospheres: Influence on consumer acceptability. Postharvest Biology and Technology, Amsterdam, v.50, p.135-144, 2008

FONTES, R.V.; SANTOS, M. P.; FALQUETO, A.T.; SILVA, D. M. Atividade da pectinametilesterase e sua relação com a perda de firmeza da polpa de mamão cv. Sunrise Solo e Tainung. Revista Brasileira de Fruticultura, Jaboticabal, v.30, n.1, p.54-58, 2008
HAN, J.H.; TAO. W.; HAO, H.; ZHANG, B.; JANG, W.; NIU, T.; LI, Q.; CAI, T. Physiology and quality responses of freshcut broccoli florets pretreated with ethanol vapor. Journal of Food Science, Hoboken, v.71, n.5, p.385-389, 2006.

JIN, Y. Z.; LV, D.Q.; LIU, W.W.; QI, H. Y.; BAI, X. H. Ethanol vapor treatment maintains postharvest storage quality and inhibits internal ethylene biosynthesis during storage of oriental sweet melos. Postharvest Biology and Technology, Amsterdam, v.86, p.372-380, 2013.

\section{KAR e MISHRA (1976) consta na p.5 linha 15}

LARSEN, M.; WATKINS, C. B. Firmness and concentrations of acetaldehyde, ethyl acetate and ethanol in strawberries stored in controlled and modified atmospheres. Postharvest Biology and Technology, Amsterdam, v.5, p.39-50. 1995.

LICHTER, A.; GABLER, F.M.; SMILANICK, J.L. Control os spoilage in table grapres. Stewart Postharvest Review, Quebec, v.6, n.1, p.1-10, 2006.

\section{LOULAKAKIS et al., 2006 consta na p.9 linha 8}

NUNES, R. C.A.; VIANA, R.S.; NETO, N.B.M. Atividade enzimática da superóxido dismutase em resposta aos fitorreguladores em Gerbera jamensonii. Comunicata Scientiae, Piauí, v.6, n.1, p.83-89, 2015.

PALAPOL, Y.; KETSA, S.; STEVENSON, D.; COONEY, J.M.; ALLAN, A.C.; FERGUSON, I.B. Colour development and quality of mangosteen (Garcinia Mangostana L.) fruit during ripening and after harvest. Postharvest Biology and Technology, Amsterdam, v.51, n.3, p.349-353, 2009.

PESIS, E. The role of the anaerobic metabolites, acetaldehyde and ethanol, in fruit ripening, enhancement of fruit quality and fruit deterioration. Postharvest Biology and Technology, Amsterdam, v.37, n.1, p.1-19, 2005 .

PESIS, E; FAIMAN, D; DORI, S. Postharvest effects of acetaldehyde vapour on ripening related enzyme activity in avocado fruit. Postharvest Biology and Technology, Amsterdam, v.13, n.3, p.245-253, 1998.

PINO, J.A.; QUIJANO, C.E. Study of the volatile compounds from plum (Prunus domestica L. cv. Horvin) and estimation of their contribution to the fruit aroma. Ciência e Tecnologia de Alimentos, Campinas, v.32, n.1, p.76-83, 2012. 
R CORE TEAM. R: A language and Environment for statistical computing. Vienna: R Foundation for Statistical Computing, 2016.

RITENOUR, M.A.; MANGRICH, M.E.; BEAULIEU, J.C.; RAB, A.; SALTVEIT, M.E. Ethanol effects on the ripening of climacteric fruit. Postharvest Biology and Technology, Amsterdam, v.12, n.1, p.35-42, 1997.

SINGH, S.P.; SINGH, Z. Postharvest cold storageinduced oxidative stress in Japanese plums (Prunus salicina Lindl. cv. Amber Jewel) in relation to harvest maturity. Australian Journal of Crop Science, Lindfield, v.7, n.3, p.391-400, 2013.

SINGH, S.P.; SINGH, Z. Role of membrane lipid peroxidation, enzymatic and non-enzymatic antioxidative systems in the development of chilling injury in japanese plums. Journal of the American Society for Horticultural Science, Alexandria, v.137, n.6, p.473-81, 2012.

STANGER, M. C.; STEFFENS, C.A.; AMARANTE, C.V.T.; BRACKMANN. A.; ANESE, R.O. Quality preservation of 'laetitia' plums in active modified atmosphere storage. Revista Brasileira de Fruticultura, Jaboticabal, v.39, n.2, p.1-7, 2017.

STANGER, M. C.; STEFFENS, C.A.; AMARANTE, C.V.T.; CORRÊA, T. R.; TANAKA, H. Qualidade póscolheita de ameixas 'Camila'e 'Laetitia'colhidas em diferentes estádios de maturação. Revista Caatinga, Mossoró, v.27, n.2, p.214- 221, 2014.
STEFFENS, C.A.; AMARANTE, C.V.T.; ESPINDOLA, B.P.; HEINZEN, A.S.; BRACKMANN, A.; BOTH, V. Ameixas 'Laetitia' armazenadas em atmosfera controlada com indução de perda de massa e manejo do etileno. Revista Caatinga, Mossoró, v. 31, n. 1, p. 225 $-234,2018$.

STEFFENS, C.A.; TANAKA, H.; AMARANTE, C.V.T.; BRACKAMANN, A.; STANGER, M.C.; HENDGES, M.V. Condições de atmosfera controlada para armazenamento de ameixas 'Laetitia' tratadas com 1-metilciclopropeno. Revista Ciência Agronômica, Fortaleza, v. 44, n. 4, p. 750-756, 2013. (1)

TZORTZAKIS, N.G.; ECONOMAKIS, C.D. Maintaining postharvest quality of the tomato fruit by employing methyl jasmonate and ethanol vapor treatment. Journal of Food Quality, United Kingdom, v. 30, n. 5, p. 567580, 2007.

WEBER,A.;BRACKMANN,A.;BOTH, V.;PAVANELLO, E.P.; ANESE, R.O.; SCHORR, M.R. Ethanol reduces ripening of 'Royal Gala' apples stored in controlled atmosphere. Anais da Academia Brasileira de Ciências, Rio de Janeiro, v.88, n.1, p.403-410, 2016.

WRIGHT, A. H.; DELONG, J.M.; ARUL, J.; PRANGE, R.K. The trend toward lower oxygen levels during apple (Mallus $x$ domestica Borkh) storage - A review. Journal of Horticultural Science \& Biotechnology, Ashford, v.90, n,1. p.1-13, 2015. 